\title{
A Meta-analysis of Studies Published in Arboriculture \& Urban Forestry Relating to Organic Materials and Impacts on Soil, Tree, and Environmental Properties
}

\author{
Bryant C. Scharenbroch
}

\begin{abstract}
Organic materials are commonly used in urban landscapes to improve soil quality and tree health. Literature reviews suggest that the effects of organic materials are beneficial, but these impacts have yet to be evaluated using meta-analytical approach. This work presents a literature summary of 176 articles published in Arboriculture \& Urban Forestry (AUF) and evaluates 33 of these papers using a meta-analysis. Research relevant to this topic is not published solely in $A U F$, but the meta-analysis is limited to $A U F$ in an attempt to specifically focus on the information provided to $A U F$ readers. This meta-analysis provides evidence of the mostly positive impacts organic materials have on shoot growth, root growth, tree physiology, and soil physical properties. It also identifies specific gaps in AUF literature for the effects organic materials have on soil chemical, soil biological, and environmental (e.g., climate, competition) properties. Further, this meta-analysis suggests the type of organic material and the mode of application have differential effects on tree, soil, and environmental properties.

Key Words. Environment; Meta-Analysis; Organic Materials; Soil Organic Matter; Soil Biological Properties; Soil Chemical Properties; Soil Physical Properties; Tree Health.
\end{abstract}

Soil organic matter (SOM) is derived from the decay of once living organisms and is composed of organic (C-based) compounds (Brady and Weil 2008). Organic matter is the most complex, dynamic, and reactive soil component (Tabatabai 1996). It positively contributes to tree and environmental health, through effects on soil physical, chemical, and biological properties (Magdoff et al. 1996). In urban landscapes, natural tree restitution avenues (e.g., leaf-litter fall) are often interrupted and as a result SOM dynamics altered (Craul 1985; Craul 1999). Consequently, organic materials are commonly applied as mulches and soil amendments to restore SOM inputs. A recent review by Chalker-Scott (2007) identified organic mulches consistently rated as the best or second best mulches for overall plant performance in comparative field trials.

Arboriculture \& Urban Forestry (AUF), formerly Journal of Arboriculture, is a primary source for the exchange of scientific knowledge in the profession of arboriculture and urban forestry. This meta-analysis was limited to results published in $A U F$ in order to assess information provided by $A U F$. Arboriculture \& $U r$ ban Forestry has a wide circulation among professional arborists and urban foresters, and these practitioners rely on the scientific journal as a main source of scientific information for the care and management of urban trees. Furthermore, most arborists and urban foresters do not subscribe to technical soil science journals, such as Soil Science Society of America Journal, Journal of Environmental Quality, or Soil Science, and it is likely they acquire most of their soil-related technical knowledge through $A U F$. Consequently, a meta-analysis limited to $A U F$ will assess the information that urban tree care professionals have been exposed to pertaining to organic materials. A recognized shortcoming of limiting a metaanalysis to studies published in $A U F$ is that it does omit key papers published in other journals; but, by doing so the meta-analysis more accurately represents information available to the arboriculture profession. Because the meta-analysis was limited to $A U F$, it is a comprehensive examination of literature in this journal.

A meta-analysis (i.e., an analysis of analyses) provides an alternative analytical framework for the synthesis of results from separate studies (Cooper and Hedges 1994; Curtis 1996). Metaanalytical approaches have been used to synthesize research and examine ecological questions relating to competition (Gurevitch and Hedges 1993), elevated CO (Curtis 1996), and animal ecology (e.g., Jarvinen 1991; Poulin 1994). A meta-analytical review involves a literature search to identify appropriate and relevant studies to answer a particular question. Treatment responses (i.e., \% change relative to control or effect size) are calculated across independent studies for standardization, and then statistically evaluated to provide information for the question of interest (Curtis 1996).

The goal of the study was to assess information in the journal Arboriculture \& Urban Forestry pertaining to the effects of organic materials on trees, soil, and environmental properties. The specific objectives of this study were: 1 ) perform a literature search and summary of $A U F$ literature relating to organic materials; 2) identify studies meeting the specific criteria for inclusion in a meta-analysis; 3) compile parameter response data for those studies; and, 4) perform a meta-analysis to examine the impacts of organic materials on trees, soils, and the environment as presented in $A U F$.

\section{METHODS}

Every article of Arboriculture \& Urban Forestry (1975 to 2008) was surveyed to address the question of how organic materials impact trees, soil, and the environment. Organic treatments were defined as C-based materials (e.g., organic mulch and compost), 
but did not include treatments such as biological inoculants and plant growth hormones. Our literature search of $A U F$ produced 176 studies that related in some manner to organic materials. Of those studies, only 33 (Table 1) met our criteria for the metaanalysis. Our criteria for inclusion in the meta-analysis were that studies needed to: 1) provide data; 2) examine an organic treatment(s); 3) have a scientific control; and, 4) show significant results $(\mathrm{p} \leq 0.05)$. Results and conclusions from the remaining
143 studies not included in the meta-analysis were assessed and compiled in the first section of the discussion labeled, qualitative summary of literature search. These 143 studies were not included in the meta-analysis, but are included in the discussion because they provide a historical framework for the topic of interest.

Treatment effects were quantified by computing $\%$ change $(\Delta)$ relative to the control, where, $X_{t}$ is the mean treatment response and $\mathrm{X}_{\mathrm{c}}$ is the control (Equation 1) (Cooper and Hodges

Table 1. Species, specifications, soil types, and characteristics of organic materials for studies used in this meta-analysis.

\begin{tabular}{|c|c|c|c|c|c|c|c|}
\hline Code & Date & Author(s) & $\begin{array}{l}\text { Species } \\
\text { (age, size, care, concerns, etc.) }\end{array}$ & Specifications & Soil type & Type $^{z}$ & Mode $^{y}$ \\
\hline A & 1982 & Fraedrich \& Ham & Acer rubrum and A. saccharinum & herbicide & $\begin{array}{l}\text { sandy clay loam } \\
\text { sandy loam }\end{array}$ & mulch & surface \\
\hline B & 1983 & Litzow \& Pellet & Fraxinus pennsylvanica & $10 \mathrm{~cm}(\mathrm{dbh})$ & clay loam & mulch & surface \\
\hline $\mathrm{C}$ & 1988 & Hensley et al. & Magnolia grandiflora & container $2 \mathrm{yr}$ & Pope silt loam & mulch & surface \\
\hline $\mathrm{D}$ & 1988 & Watson & $\begin{array}{l}\text { Acer rubrum, A. platanoides, A. saccharum, } \\
\text { Tilia cordata, Fraxinus pennsylvanica, } \\
\text { Quercus rubra, } Q . \text { palustris }\end{array}$ & $\begin{array}{l}\text { open grown, } 20 \mathrm{yr} \text {, } \\
\text { herbicide }\end{array}$ & not specified & compost & surface \\
\hline $\mathrm{E}$ & 1988 & Myers \& Harrison & Viburnum opulus, Juniperus chinensis & $\begin{array}{l}\text { container, wetting agent, } \\
\text { fertilizer }\end{array}$ & $\begin{array}{l}\text { sandy loam, } \\
\text { perlite, peat }\end{array}$ & mulch & surface \\
\hline $\mathrm{F}$ & 1989 & Green \& Watson & Acer saccharum & bare root tillage & $\begin{array}{l}\text { compacted clay } \\
\text { subsoil }\end{array}$ & compost & surface \\
\hline G & 1990 & Appleton et al. & $\begin{array}{l}\text { Ilex crenata, Rhododendron obtusum, } \\
\text { Acer rubrum }\end{array}$ & herbicide, fertilizer & Tetotum loam & $\operatorname{mix}$ & surface \\
\hline $\mathrm{H}$ & 1990 & Himelick \& Watson & Quercus alba & 45-76 cm (dbh), fertilizer & not specified & mulch & surface \\
\hline I & 1991 & Watson & not specifcied & not specified & not specified & mulch & surface \\
\hline $\mathrm{J}$ & 1991 & Watson \& Kupkowski & $\begin{array}{l}\text { Acer saccharinum, Fraxinus pennsylvanica } \\
\text { Gleditisia triacanthos, Malus spp. }\end{array}$ & $15-58 \mathrm{~cm}(\mathrm{dbh})$ & not specified & mulch & deep surface \\
\hline $\mathrm{K}$ & 1992 & Smith \& Rakow & Fraxinus pennsylvanica, Malus spp. & bare root whips $0.9 \mathrm{~m}(\mathrm{ht})$ & sandy loam & mulch & surface \\
\hline $\mathrm{L}$ & 1992 & Watson et al. & Fraxinus pennsylvanica & $\mathrm{B} \& \mathrm{~B}$, hole shapes & $\begin{array}{l}\text { compacted clay } \\
\text { subsoil }\end{array}$ & compost & backfill \\
\hline M & 1993 & Zajicek & Lagerstroemia indica & $1 \mathrm{yr}$, inground pots & $\begin{array}{l}66 \% \text { fritted clay } \\
33 \% \text { peat-lite }\end{array}$ & mulch & surface \\
\hline $\mathrm{N}$ & 1994 & Lichter \& Lindsey & not applicable & fabric, compaction & silt loam & mulch & deep surface \\
\hline $\mathrm{O}$ & 1995 & Duchesne \& Clark & Thuga occidentalis & seeds & O-Ae-B horizons & mulch & surface \\
\hline $\mathrm{P}$ & 1995 & Greenly \& Radkow & Pinus strobus, Quercus palustris & $\begin{array}{l}\text { bare root and B\&B } 3-5 \mathrm{~cm} \text { (cal), } \\
1.2-1.5 \mathrm{~m}(\mathrm{ht})\end{array}$ & $\begin{array}{l}\text { Collamer silt } \\
\text { loam }\end{array}$ & mulch & deep surface \\
\hline Q & 1995 & Smalley \& Wood & Acer rubrum & $\mathrm{B} \& \mathrm{~B} 3 \mathrm{~cm}(\mathrm{cal})$ & Cecil sandy loam & $\operatorname{mix}$ & backfill \\
\hline $\mathrm{R}$ & 1996 & Watson et al. & Quercus alba, Tilia spp., Platanus acerfolia & $8.3,9.1,12.4 \mathrm{~cm}(\mathrm{dbh})$ & not specified & compost & backfill \\
\hline S & 1999 & Duryea et al. & Lactuca spp. & seed & filter paper & $\operatorname{mix}$ & surface \\
\hline $\mathrm{T}$ & 1999 & Foshee et al. & Carya illinoensis & container, fertilization & $\begin{array}{l}\text { Cahaba fine } \\
\text { sandy loam }\end{array}$ & $\operatorname{mix}$ & deep surface \\
\hline $\mathrm{U}$ & 1999 & Iles \& Dosman & Acer rubrum & $\begin{array}{l}\text { bare root, } 1.6-2.0 \mathrm{~cm}(\mathrm{cal}) \text {, } \\
\text { herbicide }\end{array}$ & $\begin{array}{l}\text { Nicollet fine } \\
\text { sandy loam }\end{array}$ & mulch & surface \\
\hline V & 2002 & Watson & Quercus alba & $79 \mathrm{~cm}(\mathrm{dbh})$ & not specified & compost & backfill \\
\hline W & 2004 & Gilman & Quercus virginia & $\begin{array}{l}\text { container, } 5.1 \mathrm{~cm}(\mathrm{cal}) \text {, } \\
\text { irrigation }\end{array}$ & $\begin{array}{l}\text { Milhopper fine } \\
\text { sand }\end{array}$ & compost & backfill \\
\hline $\mathrm{X}$ & 2004 & Gilman \& Grabosky & Quercus virginia & $6.5 \mathrm{~cm}$ (cal), herbicide & $\begin{array}{l}\text { Milhopper fine } \\
\text { sand }\end{array}$ & mulch & surface \\
\hline $\mathrm{Y}$ & 2005 & Ferrini et al. & Quercus robur & $\begin{array}{l}\mathrm{B} \& \mathrm{~B} ; 5 \mathrm{yr}, 4.5 \mathrm{~m}(\mathrm{ht}) \\
13 \mathrm{~cm}(\mathrm{dbh}), \text { fertilization }\end{array}$ & clay & compost & backfill \\
\hline $\mathrm{Z}$ & 2005 & Arnold et al. & $\begin{array}{l}\text { Fraxinus pennsylvanica, Koelreuteria } \\
\text { bipinnata }\end{array}$ & $\begin{array}{l}126 \mathrm{~cm}(\mathrm{ht}), 88 \mathrm{~cm}(\mathrm{ht}) \\
\text { planting depth, fertilization }\end{array}$ & $\begin{array}{l}\text { Bonnville fine } \\
\text { sandy loam }\end{array}$ & mulch & deep surface \\
\hline $\mathrm{a}$ & 2006 & Scharenbroch \& Lloyd & various deciduous & 2 to $7 \mathrm{~m}(\mathrm{ht})$ & Paulose silt loam & mulch & surface \\
\hline $\mathrm{b}$ & 2006 & Roberts & Acer rubrum, Fraxinus pennsylvanica & $\begin{array}{l}\text { plug seedlings, bare root, } 2 \mathrm{yr} \text {, } \\
\text { fertilization }\end{array}$ & not applicable & $\operatorname{mix}$ & backfill \\
\hline $\mathrm{c}$ & 2007 & Ferrini \& Baietto & Acer platanoides & $\begin{array}{l}\mathrm{B} \& \mathrm{~B}, 5 \mathrm{yr}, 4.5 \mathrm{~m}(\mathrm{ht}) \\
15 \mathrm{~cm}(\mathrm{dbh}) \text {, covering type }\end{array}$ & clay loam & compost & surface \\
\hline d & 2007 & Rivenshield \& Bassuk & not applicable & compaction, wetting agent & sandy loam & $\begin{array}{l}\text { clay } \\
\text { loam }\end{array}$ & $\begin{array}{l}\text { compost } \\
\text { backfill }\end{array}$ \\
\hline $\mathrm{e}$ & 2007 & Montague et al. & $\begin{array}{l}\text { Lagerstroemia indica, Forsythia } \\
\times \text { intermedia, Spirea } \times \text { vanhouttei, } \\
\text { Photinia } \times \text { fraser } i\end{array}$ & container, irrigation & $\begin{array}{l}\text { Austin silty } \\
\text { clay }\end{array}$ & mulch & surface \\
\hline $\mathrm{f}$ & 2008 & Singer \& Martin & not applicable & aridity & $\begin{array}{l}\text { Rillito gravelly } \\
\text { loam }\end{array}$ & mulch & surface \\
\hline g & 2008 & Ferrini et al. & Tilia $\times$ europaea, Aesculus $\times$ carnea & $\begin{array}{l}\mathrm{B} \& \mathrm{~B}, 3 \text { to } 4 \mathrm{~cm}(\mathrm{dbh}) \\
\text { herbicide }\end{array}$ & not specified & mulch & surface \\
\hline
\end{tabular}

${ }^{\mathrm{z}}$ Mulch materials include: tree trimmings, wood chips, hay, chunk and shredded bark; composted materials include: food, humic acids, yard waste, leaves, grass clippings.

${ }^{\text {y }}$ Surface applications are application of 0 to $10 \mathrm{~cm}$; deep surface application are $>10 \mathrm{~cm}$; backfill amendments applied below the surface. 
1994). The effect size parameter (d) was calculated with (s), the pooled standard deviation of the means and $(\mathrm{J})$ a weighting term that approaches one as sample size increases (Cooper and Hodges 1994) (Equation 3). The weighting factor (J) was calculated with treatment replication, $\mathrm{n}_{\mathrm{t}}$ and control replication, $\mathrm{n}_{\mathrm{c}}$ (Cooper and Hodges 1994) (Equation 2). The effect size parameter (d) is very important as it corrects for an overestimation bias when sample sizes are small (Cooper and Hodges 1994), and $\mathrm{d}$ can be used for statistical tests of unequal sample sizes (Hunter and Schmidt 2004). Effect size will increase with increasing $\%$ change, decreasing variance, and increasing sample size. Consequently, effect size values close to zero (i.e., -0.2 to 0.2) relate weak responses relative to values farther from zero.

$$
\begin{aligned}
& \% \text { change }(\Delta)=\left[\left(X_{t}-X_{c}\right) / X_{c}\right] * 100 \\
& \text { Weighting factor }(J)=1-\left(3 /\left(4 *\left(n_{t}+n_{c}-2\right)-1\right)\right. \\
& \text { Effect size }(d)=(\Delta / s) * J
\end{aligned}
$$

Treatment effects ( $\Delta$ and d) were coded as positive or negative according to their interpreted impact on tree, soil, or environmental quality. For instance, a significant decrease in bulk density due to an organic treatment was assigned positive $\Delta$ and d values, even though the observed treatment response was a decrease relative to the control. Treatment effects were only calculated for data showing significant $(\mathrm{p} \leq 0.05)$ response on at least half of the data presented. For example, if soil temperature under mulch was significantly less than under bare ground on six of the ten measured dates, then treatment effects were quantified. Conversely, if soil $\mathrm{pH}$ was only significantly less under mulch compared to turf at one of the six measured depths, treatment effects were not quantified. The 33 studies in the meta-analysis spanned many different tree species, growing conditions, soil types, organic treatments, controls, and potential treatment interactions (Table 1). Details on species, soil characteristics, and other specifications (ages, care, potential interactions, etc.) were used for data interpretation.

Meta-analysis class variables (i.e., attribute categories) were established to lump significant responses into ecologically heterogeneous groups (Lipsey 1994). All significant responses were coded into the following seven attribute categories: 1) shoot growth, 2) root growth, 3) physiological, 4) soil chemical, 5) soil physical, 6) soil biological, and 7) environmental (Table 2 ). Treatment groups were identified according to the type of organic material (mulch, compost, and mix of mulch and compost) and mode of application [deep surface $>10 \mathrm{~cm}$ (4 in), surface 0 to $10 \mathrm{~cm}$ (0 to $4 \mathrm{in}$ ), and applied as in backfill] (Table 1).

Statistical tests were performed to identify differences relating to the type of organic material (mulch, compost, or mix) and mode of application (surface, deep surface, or backfill). The interaction between type and mode of application was not significant for any of seven attribute categories $(\mathrm{p} \geq 0.844)$. However, the availability of data likely limited our ability to adequately test for this interaction. No studies reported data for mulch as backfill or compost as a deep surface application. Only two studies used mixed materials as backfill. Only three studies reported data for compost applied to the surface and mixed materials on the surface. Other statistical tests were performed, such as the effect of experimental realm (e.g., field versus container environment), but these tests did not reveal any significant $(\mathrm{p} \geq 0.270)$ differences in field versus container studies for the entire data set or for any of the attribute categories.

Frequency distributions were compiled and data normality was tested with the Shapiro-Wilk test (SAS 2005). Analysis of variance with Tukey-Kramer HSD and Student's t-test were used to identify significant differences for various statistical tests (SAS 2005). All statistical differences are reported at the $\mathrm{p} \leq 0.05$ probability level.

\section{RESULTS}

In total, 79 significant tree, soil, and environmental responses were identified in 33 studies (Figure 1). The distribution for percentage change $(\Delta)$ was nonnormal $(\mathrm{W}=0.778$; $\mathrm{p}<0.0001)$ and heavily weighted $(69 \%)$ in the $0 \%$ to $100 \%$ response relative to control range (Figure 1). The mean $\Delta$ for all significant responses was 44.8 ( $\mathrm{SE} \pm 9.1)$, and this value was significantly $(\mathrm{p}<0.0001)$ greater than a null hypothesis, zero response (Figure 1). The effect size (d) parameter removed the bias associated with small sample sizes. The distribution of $d$ was also nonnormal $(\mathrm{W}=0.581 ; \mathrm{p}<0.0001)$ and heavily weighted $(83 \%)$ in the zero to one response range (data not depicted). The mean $d$ value for all responses was $0.58(\mathrm{SE} \pm 0.2)$; also significantly greater than a null response of zero $(p=0.0034)$.

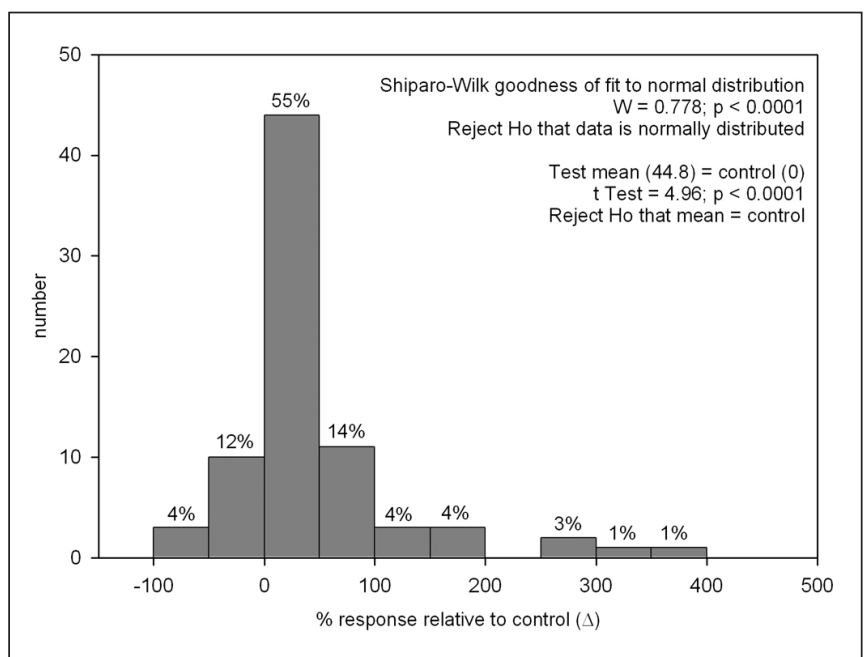

Figure 1. Frequency distribution of $\%$ response relative to control $(\Delta)$ for seventy-nine significant tree, soil, and environmental attribute responses to organic materials, detected in $\mathbf{3 3}$ studies.

The distribution of significant responses among attribute categories was: shoot growth (18), root growth (9), physiological (20), soil chemical (5), soil physical (18), soil biological (4), and environmental (5) (Figure 2; Table 2). Significant differences were identified for both $\Delta$ and d across these attribute categories (Figure 2). Percent response relative to control was significantly $(p=0.0028)$ greater for soil biological $(160.0)$ compared to environmental (7.2), soil chemical (10.8), physiological (25.2), shoot growth (34.7), and soil physical (36.8) (Figure 2). Although not significant, root growth $\Delta(113.7)$ was less than soil biological and greater than other attribute categories (Figure 2). The d value was significantly $(\mathrm{p}=0.0444)$ greater for soil physical $(2.10)$ compared to soil biological $(0.00)$, environmental $(0.00)$, physiologi- 
cal (0.29), and shoot growth (0.46) (Figure 2). Soil chemical (1.02) and root growth (1.15) d values were intermediate (Figure 2).

Response parameters with the most number of significant detections included root density (7), soil moisture (7), soil temperature (7), tree diameter (6), shoot growth (6), transpiration (5), and tree height (4) (Table 2). Twenty-six of the 35 response variables $(74 \%)$ had mean values that were positive. The greatest $\Delta$ positive values were for mycorrhizae density (324), germination (169), litter (158), root density (138), particulate organic matter (120), and soil porosity (103) (Table 2). Fourteen $\mathrm{d}$-values were positive and two were negative (Table 2). Nineteen d-values were zero; indicating only one significant data point for that particular response parameter. The greatest positive $\mathrm{d}$ values were for soil porosity (4.9), soil $\mathrm{pH}$ (4.1), soil moisture (1.8), transpiration (1.6), and root density (1.4) (Table 2).

The mode of organic material application had a significant impact on soil physical properties (Figure 3). The mean $\Delta$ response was significantly $(\mathrm{p}=0.0046)$ greater for studies that applied organics as backfill compared to those that applied organics to the surface and deep surface applications. Shoot growth tended $(p=0.1066)$ to be negatively impacted by backfill amendments compared to surface applications.

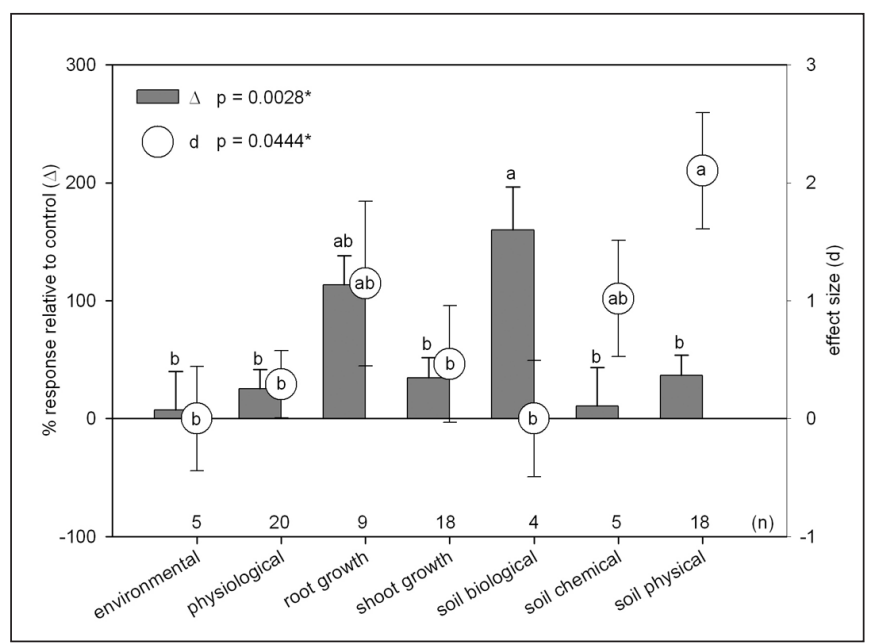

Figure 2. Mean \% response relatives to control $(\Delta)$ [bars] and effect size (d) [circles] for the effects of organic materials on ecological attribute categories. Significant $(p \leq 0.05)$ differences for each matrix are identified by different letters. Errors bars indicate the $95 \%$ confidence interval. Numbers show the sample size.

Table 2. Attribute categories, mean \% responses relative to control $(\Delta)$ with standard error estimates of mean (SE), effect sizes (d), and citations for response parameters used in this study.

\begin{tabular}{|c|c|c|c|c|c|}
\hline Response parameter & Attribute category & $\Delta$ & SE & d & Reference $^{z}$ \\
\hline tree height & shoot growth & 14.8 & 14.2 & 0.5 & ACWa \\
\hline tree diameter & shoot growth & 50.2 & 23.5 & 0.9 & ABCFXg \\
\hline shoot increment & shoot growth & 46.8 & 34.8 & 0.6 & ACFPbg \\
\hline shoot biomass & shoot growth & -8.0 & 43.0 & -0.1 & be \\
\hline root density & root growth & 137.6 & 27.6 & 1.4 & DFILQRV \\
\hline root biomass & root growth & 30.0 & 20.0 & 0.9 & We \\
\hline survival & physiological & -3.0 & 0.0 & 0.0 & $\mathrm{Z}$ \\
\hline germination & physiological & 169.0 & 227.0 & 0.4 & OS \\
\hline root to shoot & physiological & 30.0 & 0.0 & 0.0 & $\mathrm{~b}$ \\
\hline leaf color & physiological & 27.0 & 0.0 & 0.0 & $\mathrm{H}$ \\
\hline leaf biomass & physiological & -16.0 & 61.0 & -0.1 & $\mathrm{bc}$ \\
\hline leaf stress & physiological & -37.0 & 0.0 & 0.0 & Z \\
\hline leaf phosphorus & physiological & -41.0 & 0.0 & 0.0 & $\mathrm{H}$ \\
\hline leaf manganese & physiological & 9.0 & 0.0 & 0.0 & $\mathrm{U}$ \\
\hline photosynthesis & physiological & 18.5 & 13.5 & 0.8 & Yc \\
\hline chlorophyll & physiological & 26.5 & 18.5 & 0.8 & Yc \\
\hline water use efficiency & physiological & 13.0 & 0.0 & 0.0 & c \\
\hline transpiration & physiological & 22.0 & 6.1 & 1.6 & KMXcg \\
\hline soil moisture & soil physical & 45.9 & 9.7 & 1.8 & ABDGIPT \\
\hline soil temperature & soil physical & 13.3 & 5.4 & 0.9 & ABEGPTf \\
\hline soil density & soil physical & 20.5 & 15.5 & 0.8 & $\mathrm{HN}$ \\
\hline soil porosity & soil physical & 103.0 & 12.0 & 4.9 & $\mathrm{Yd}$ \\
\hline soil nitrate & soil chemical & -33.0 & 0.0 & 0.0 & $\mathrm{~J}$ \\
\hline soil potassium & soil chemical & 30.0 & 0.0 & 0.0 & $\mathrm{U}$ \\
\hline soil pH & soil chemical & 10.9 & 1.1 & 4.1 & HT \\
\hline total SOM & soil chemical & 35.0 & 0.0 & 0.0 & a \\
\hline litter & soil biological & 158.0 & 0.0 & 0.0 & $\mathrm{a}$ \\
\hline particulate organic matter & soil biological & 120.0 & 0.0 & 0.0 & $\mathrm{a}$ \\
\hline carbon mineralization & soil biological & 38.0 & 0.0 & 0.0 & a \\
\hline mycorrhizae density & soil biological & 324.0 & 0.0 & 0.0 & $\mathrm{H}$ \\
\hline long wave radiation & environmental & -35.0 & 0.0 & 0.0 & $\mathrm{f}$ \\
\hline surface temperature & environmental & -38.0 & 0.0 & 0.0 & M \\
\hline air temperature & environmental & -15.0 & 0.0 & 0.0 & M \\
\hline evaporation & environmental & 44.0 & 0.0 & 0.0 & $\mathrm{~K}$ \\
\hline weed density & environmental & 80.0 & 0.0 & 0.0 & $\mathrm{P}$ \\
\hline all & & 44.8 & 9.1 & 0.6 & 79 \\
\hline
\end{tabular}

Reference codes are identified in Table 1. 
The mean $\Delta$ across all attribute categories was greater $(\mathrm{p}=$ 0.1044 ) for backfill compared deep surface organic application.

The type of organic material had significant impacts across all attribute categories and on physiological attributes (Figure 4). Studies that used compost materials had significantly $(\mathrm{p}=0.0012)$ greater $\Delta$ values compared to studies with mulch or a mixed materials. Physiological $\Delta$ values were significantly $(\mathrm{p}=0.0326)$ greater for compost and mulch studies compared to studies using a mix. Shoot growth, root growth, and soil physical $\Delta$ were greater $(\mathrm{p}=0.1282,0.3237$, and 0.1171 , respectively) for compost studies compared to mulch and mix.

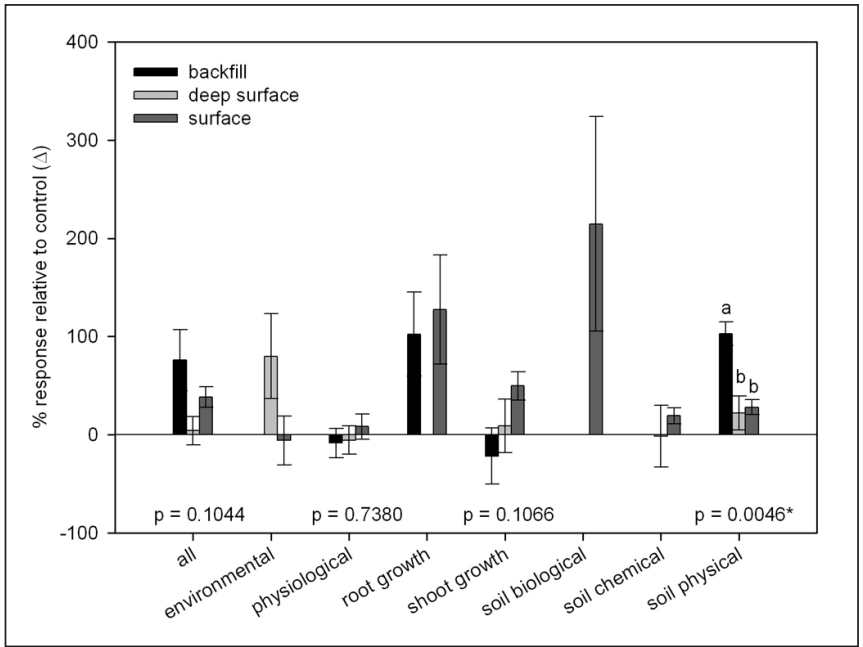

Figure 3. Mean $\%$ response relative to control $(\Delta)$ for surface mulches $(0-10 \mathrm{~cm})$, deep surface mulches $(>10 \mathrm{~cm})$, and backfill organic amendments across ecological attribute categories. Significant $(p \leq 0.05)$ differences for each are identified by different letters. Errors bars indicate the $95 \%$ confidence interval.

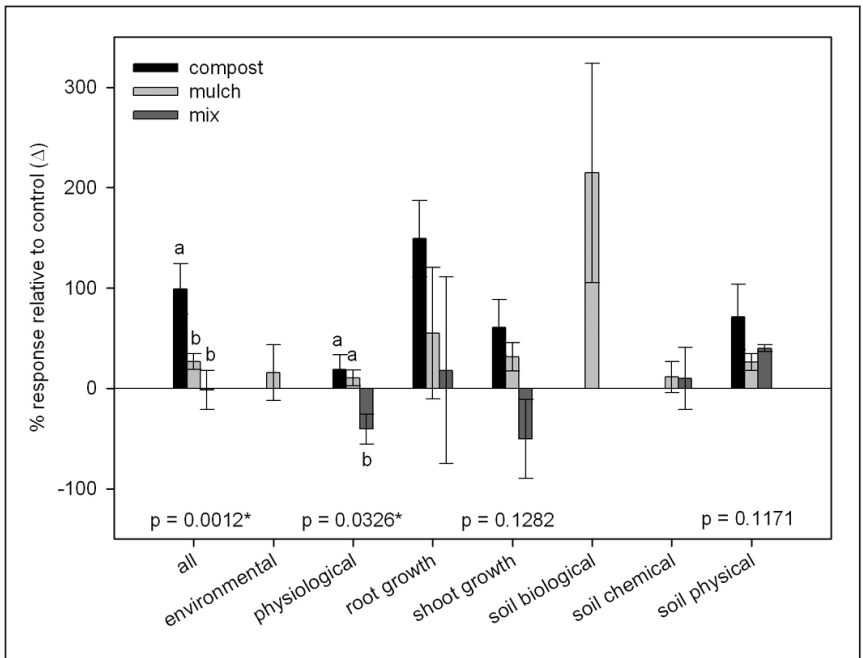

Figure 4 . Mean \% response relative to control $(\Delta)$ for compost, mulch, and mixed organic materials across ecological attribute categories. Significant $(p \leq 0.05)$ differences for each are identified by different letters. Errors bars indicate the $95 \%$ confidence interval.

\section{DISCUSSION}

\section{Summary of Literature Search}

Trends and conclusions from the 143 studies not included in the meta-analysis were compiled and are summarized in the following section. Although only selected references are given for the general trends, a full bibliography of these studies can be acquired by contacting the author.

Studies published in the Journal of Arboriculture in the 1970s were often qualitative tree evaluations. These studies suggest: 1) inorganic fertilization is required for establishment and maintenance; 2) organic material may be beneficial for tree establishment; 3) organic material may have benefits for controlling weeds and root rots; 4) plastic under mulch should be avoided; and 5) organic mulches are alternative uses of arboricultural waste (e.g., Hoitink et al. 1975; Schulte and Whitcomb 1975; Swisher 1976; Walker 1977; Smith 1979; Whitcomb 1979).

In the 1980s, the Journal of Arboriculture published more quantitative data on tree and soil responses to organic materials. Studies published in the 1980s: 1) increased awareness of the importance of soils and site factors for urban tree growth; 2) showed that the effects of inorganic mulches on trees and soils are different compared to organic mulches; 3 ) demonstrated that the environment under organic mulches is quite different from under turf-grass (e.g., Whitcomb 1980; Hamilton et al. 1981; Peck 1981; van de Werken 1981; Whitcomb 1981; Funk 1983; Craul 1985; Dyer and Mader 1986; Kozlowski 1987).

During the 1990s, the Journal of Arboriculture continued to publish more quantitative data on tree and soil, as well as, environmental responses to organic materials. Research in the 1990s suggested that: 1) organic materials have many benefits as soil surface covers; 2) urban soil organic matter cycling is unique from other systems; 3 ) organic materials may be useful to offset inorganic fertilization; 4) biological inoculants and plant growth hormones may have benefits for urban soils and trees (e.g., Dixon and Johnson 1992; Wager and Barker 1993; Craul 1994; Cregg 1995; Burch et al. 1996; Close et al. 1996; Marx et al. 1997; Smiley et al. 1997; McPherson 1998; Perry and Hickman 1998).

From the years 2000 to 2008, studies relating to organic materials published in Journal of Arboriculture and AUF detailed: 1) chemical and physical properties of mulches; 2) depth and placement mulches; 3) pathogens and flammability of mulches; 4) reviews of $\mathrm{N}$ availability and tree fertilization; 5) effects on soil biology and urban ecological function (e.g., Jin et al. 2002; Nowak et al. 2002; Struve 2002; Steward et al. 2003; Koski and Jacobi 2004; Scharenbroch and Lloyd 2004; Jacobs 2005; Wells et al. 2006; Day and Harris 2007).

The Arboriculture \& Urban Forestry literature search showed that organic materials are a relevant $A U F$ topic. Some recurring themes pertaining to organic materials in $A U F$ literature relate to specifics of type of organic, how it is placed (i.e., mode), and quantification of impacts on trees, soil, and the environment. The following sections discuss these themes in the context of this meta-analysis.

\section{Type of Organic Material}

In general, mulches in these studies were coarser organic materials from tree trimmings, wood chips, hay, bark, etc. (Table 1). Compost was finer, more stabilized organic material, and mixed material contained some of both types. Most studies in 
$A U F$ did not provide specific chemical information (e.g., $\mathrm{C} / \mathrm{N}$ ratios) for the organic materials. Twigs, wood chips, dead leaves, and residues of dead plants are rich in $\mathrm{C}$ and low in $\mathrm{N}$ and these materials often have $\mathrm{C} / \mathrm{N}$ ratios exceeding 200/1 (Stratton et al. 1995). As substrates are decomposed (i.e., composted), C is lost via respiration and $\mathrm{N}$ is gained through immobilization, thus substrate $\mathrm{C} / \mathrm{N}$ will decrease with time, and $\mathrm{C} / \mathrm{N}$ of compost is commonly observed to be $20 / 1$ to $35 / 1$ (Stratton et al. 1995).

Microbial decomposition and mineralization kinetics of organic materials are controlled by substrate quality (e.g., $\mathrm{C} / \mathrm{N}$ ratio, lignin, and polyphenol content) and environmental conditions (e.g., temperature, water, oxygen, and $\mathrm{pH}$ ) (Bardgett 2005). Nitrogen immobilization occurs when the $\mathrm{C} / \mathrm{N}$ ratio of the substrate exceeds approximately $20 / 1$ to $25 / 1$ (Sylvia et al. 1999). Lignin contents greater than $20 \%$ and polyphenol contents greater than $3 \%$ are suspected to slow decomposition (Melillo et al. 1982; Northup et al. 1995). Relative to $\mathrm{C} / \mathrm{N}$ ratios, even less study has been directed to lignin and polyphenol content of urban landscape organic materials. Duryea et al. (1999) studied the biochemical composition of mulch as it impacts lettuce seed germination, but controlled experimentation is required for impacts on trees, soils, and environmental quality.

The meta-analysis of $A U F$ literature supports others whom have found that nutrient-rich, fine-textured compost favors mineralization and is an excellent nutrient source (Lloyd et al. 2002). It is worthwhile to note that mulches made from diseased plant materials potentially contain those pathogens, thus high-temperature composting may be preferential in cases where disease may be an issue. Although compost is a fertile base, it is also a potential seed bank for weed establishment and growth (Chalker-Scott 2007). Compost is not effective at weed suppression relative to coarse mulch (Maynard 1998). This meta-analysis found greater improvements in soil physical properties with compost incorporated into the soil compared to surface-applied mulch; but, others have suggested coarser mulches may be better at water retention (Chalker-Scott 2007) and temperature buffering (Tilander and Bonzi 1997).

Tree attribute responses tended to be greater for compost relative to mulch, but both compost and mulch were associated with positive root growth, shoot growth, tree physiological responses. The negative responses associated with mixed compost-mulch studies are derived from observations of decreased germination of lettuce seeds (Duryea et al. 1999) and short-term decreases in shoot growth of containerized seedlings grown in a variety of composted biosolids (Roberts 2006).

Schulte and Whitcomb (1975) observed a decrease in tree height of young silver maples with an increase in pine bark mulch, and they attribute this decrease to a "tie-up" of nitrogen by soil microorganisms (i.e., $\mathrm{N}$ immobilization). Hensley et al. (1988) also observed a decrease in tree height with organic materials, but only during the first year, and the trend was reversed after 22 months, likely as $\mathrm{C} / \mathrm{N}$ decreased. Longterm $\mathrm{N}$ immobilization or growth suppression is not likely to occur with mulch (Greenly and Rakow 1995; Pickering and Shepherd 2000). Experimental research has found increased soil and/or foliage nutrient levels with mulch (Arthur and Wang 1999; Foshee et al. 1999; Szwedo and Maszczyk 2000).

\section{Mode of Organic Material}

Research in $A U F$ suggests backfill organic amendments improved soil physical properties relative to surface applica- tions. Particle density of organic matter is $1.0 \mathrm{~g} \mathrm{~cm}^{-3}(62.4$ $\left.\mathrm{lb} \mathrm{ft}{ }^{-3}\right)$, which is less than mineral soil, $2.65 \mathrm{~g} \mathrm{~cm}^{-3}(165.4 \mathrm{lb}$ $\mathrm{ft}^{-3}$ ) (Rühlmann et al. 2006); thus, direct incorporation of organic material in planting holes will reduce soil bulk density.

The AUF meta-analysis shows that surface applications tended to improve shoot growth, root growth, and physiological response relative to backfill amendments. It has been proposed that when backfill soil differs from the site soil, roots may have difficulty crossing the interface (Pellet 1971; Schulte and Whitcomb 1975); but, Watson et al. (1992) did not observe root confinement to planting holes with organic backfill. The interface created in the planting hole between the organic and mineral soil is likely to impact soil water movement; but, to my knowledge, this has yet to be conclusively demonstrated in experimental study. The negative responses associated with backfill applications in this metaanalysis are from decreases in shoot growth and physiological properties, reported with containerized seedlings (Roberts 2006).

This meta-analysis found that normal surface applications of 0 to $10 \mathrm{~cm}$ tended to have more positive impacts on shoot growth and physiological attributes compared to deep surface applications. Arnold et al. (2005) reported negative impacts of decreased water penetration, increase soil tension, decreased shoot growth and increased plant stress with $>15 \mathrm{~cm}$ (6 in) of mulch. Conversely, Watson and Kupkowski (1991) did not observe detrimental effects on root density, temperature, moisture, or aeration from $45 \mathrm{~cm}$ (18 in) of mulch. Thicker layers of mulch may be better able to resist compaction and be beneficial as better temperature buffers and weed suppressors (Chalker-Scott 2007).

\section{Impacts of Organic Materials on Trees, Soil, and Environment}

This meta-analysis showed that $A U F$ research found that organic materials had generally positive impacts on tree, soil, and environmental parameters (Figure 2). The strongest positive responses were observed for soil physical $(\mathrm{n}=18 ; \Delta=36.8 ; \mathrm{d}=2.1)$, root growth $(\mathrm{n}=9 ; \Delta=113.7 ; \mathrm{d}=1.1)$, shoot growth $(\mathrm{n}=18 ; \Delta=34.7$; $\mathrm{d}=0.5)$, and physiological $(\mathrm{n}=20 ; \Delta=25.2 ; \mathrm{d}=0.3)$ attributes. Percent changes were highest for soil biological attributes $(n=4$; $\Delta=160.0 ; \mathrm{d}=0.0$ ), but the low sample sizes suppressed d values. Soil chemical properties had positive, but variable responses with low repetition $(\mathrm{n}=5 ; \Delta=10.7 ; \mathrm{d}=1.1)$. The detectable response for environmental attributes was minimal, likely due to low number of studies reporting these values $(\mathrm{n}=5 ; \Delta=7.2 ; \mathrm{d}=0.0$ ).

Responses to organic materials observed in the literature summary and meta-analysis are compiled in a conceptual model (Figure 5). Changes in soil physical properties associated with increased organic materials include temperature buffering, reduced evaporation, increased infiltration, increased retention, increased drainage, reduced splashing, decreased density, and increased porosity. This meta-analysis did provide substantial evidence that organic materials are associated with buffering of soil temperature, improving soil moisture status, decreasing density, and increasing porosity.

There are many proposed soil biochemical improvements from organic materials (Figure 5). However, this meta-analysis did not identify many studies in AUF literature with data showing significant improvements in chemical or biological properties. It is logical to expect that organic materials would increase SOM, but only one $A U F$ study provided significant data demonstrating this relationship (Scharenbroch and Lloyd 2006). Due to low sample sizes, we were unable to identify any trends as- 


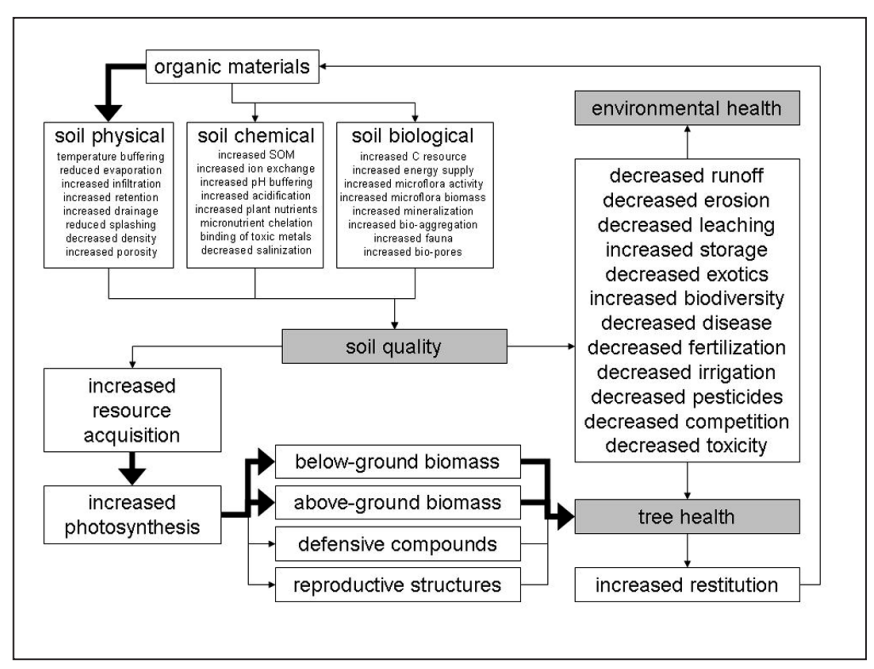

Figure 5. Conceptual model for the effects of organic materials on soil quality, tree health and environmental health. Size of arrow indicates relative support in literature published in Arboriculture and Urban Forestry.

sociated with soil available nutrients. A significant increase for potassium (Foshee et al. 1999) was detected, but Watson and Kupkowski (1991) detected a significant decrease in soil nitrate. Soil organic matter can chelate micronutrients making them more available for plant uptake (Evangelou 1998), and this is consistent with observed leaf Mn increase with organic materials (Foshee et al. 1999). The controls on the soil available nutrient pool (i.e., moisture, temperature, microbial activity) are erratic, thus a single temporal measurement of extractable nutrients is not a good indication of site fertility (Scharenbroch and Lloyd 2006).

Studies in this meta-analysis show a decrease in soil $\mathrm{pH}$ with organic materials. Although the $\mathrm{pH}$ change was consistent, conclusions drawn from this meta-analysis regarding soil $\mathrm{pH}$ should be tempered as the data is based on only two responses. One would expect that soil $\mathrm{pH}$ may be more impacted if the study were performed in a container rather than in a field setting, but the observed $\mathrm{pH}$ decreases with organic materials were observed for both conditions (Himelick and Watson 1990; Foshee et al. 1999). Studies not included in this meta-analysis suggest that acidification is generally beneficial as many urban soils are too alkaline for optimal plant nutrient availability (Kelsey and Hootmann 1988; Craul 1999). Soil organic matter is a soil acidification source via $\mathrm{H}^{+}$dissociation from carbonic acid and other acid functional groups (e.g., malic, carboxylic, and citric acids) (Evangelou 1998). Soil organic matter forms soluble complexes with nonacid cations, and as these cations leach, $\mathrm{pH}$ decreases (Sikora et al. 1996). Soil organic matter fuels microbial-mediated processes such as nitrification and sulfur oxidation, and through $\mathrm{H}^{+}$production, they acidify soils (Paul 2007).

Soil organic matter is the $\mathrm{C}$ and energy source for many soil organisms (Bardgett 2005). Consequently, activity and biomass tend to increase with increasing SOM (Sikora et al. 1996). Himelick and Watson (1990) found increased mycorrhizae infection and density with organic materials. Scharenbroch and Lloyd (2006) reported significantly greater labile substrate (i.e., particulate organic matter) and potential $\mathrm{C}$ mineralization (i.e., microbial respiration) with organic materials. This meta-analysis suggests positive impacts on soil organisms with organic materi- als, but the effects of organic materials on urban soil organism activity, biomass, and diversity have not been adequately studied.

It is probable that organic materials improve overall soil quality (e.g., decreased root resistance, increased aeration, water and nutrient availability, etc.), and these improvements would likely lead to increased resource acquisition. This meta-analysis did confirm an association between organic materials and increased shoot and root growth. There is much evidence in the literature showing that soil resources do impact physiological function (i.e., photosynthesis), $\mathrm{C}$ allocation patterns, and ultimately tree health (Matson and Waring 1984; Lorio 1986; Christiansen et al. 1987; Herms and Mattson 1992; Herms 2002; Glynn et al. 2003). Results from this meta-analysis generally support this explanation, but significant data demonstrating that organic materials directly improve soil properties, increase resource acquisition, increase photosynthesis, impact $\mathrm{C}$ allocation, and improve tree health were not available from any study in the meta-analysis.

Improvements in soil quality from organic materials can impact environmental health via numerous mechanisms (Figure 5). Organic materials protect soil and decrease losses with runoff and erosion (Lal et al. 2003). The end-products of humification (i.e., humus) are stable colloids with large exchange capacities, thus are very effective at nutrient, water, and toxin retention (Sikora et al. 1996). If organic materials are able to improve the water and nutrient status of soils, then reliance on inorganic fertilization and irrigation should decrease (Rechcigl 1995). Organic materials are proposed to create more diverse soil food webs (Coleman et al. 2004) and decrease weeds (Stinson et al. 1990), thus increasing competitive pressure on disease-causing organisms and weeds and our reliance on pesticides and herbicides. Globally, twice as much $\mathrm{C}$ is stored in the soil, $3340 \mathrm{Pg}\left(3.68 * 10^{12}\right.$ tons $)$ as in the vegetation, $550 \mathrm{Pg}\left(6.06 * 10^{11}\right.$ tons $)$ and atmosphere, $760 \mathrm{Pg}\left(8.38 * 10^{11}\right.$ tons) combined (Batjes 1996; Soloman et al. 2007); yet, benefits of soil $\mathrm{C}$ sequestration with urban organic materials were not quantified in this meta-analysis or elsewhere.

The assumption that a meta-analysis uniformly represents the final and accurate viewpoint of an area of research is not warranted. A meta-analysis has a number of areas with the potential for bias, such as the inclusion or exclusion criteria used to select the studies for the meta-analysis. A particular bias in this study is that the responses were compiled solely from $A U F$ research, and these responses may be a product of the research interests or perhaps the associated ease of measurement. On the other hand, no or low responses may suggest specific needs in $A U F$ literature for identifying the impacts organic materials have on certain parameters (e.g., soil chemical, soil biological, and environmental properties). Attempts were made to limit bias by applying relatively stringent criteria (significant results on at least half of reported data for a given response) and including a robust suite of parameters in the meta-analysis (any and all parameters measured by any study published in $A U F$ relating to organic materials).

\section{CONCLUSION}

At the coarse scale, positive responses for organic materials were detected for all attribute categories (Figure 2). Divergences in positive response occur when the type and mode of organic materials are considered separately (Figure 3; Figure 4). Studies in Arboriculture \& Urban Forestry reported more responses for 
shoot growth, root growth, physiological and soil physical properties with organic materials; and, relative to those attribute categories, soil chemical, soil biological, and environmental responses, are less reported in $A U F$ literature (Table 2; Figure 2). More AUF research is needed on the impacts of organic materials on soil biological diversity and function. Experimentation on organic materials and atmospheric quality (e.g., denitrification, $\mathrm{CO}_{2}$ efflux, etc.) and water quality (e.g., $\mathrm{N}$-leaching, $\mathrm{P}$-erosion. etc.) is scarce in $A U F$. Additional research in $A U F$ should be directed towards the mechanisms, not just associations, of how organic materials improve soil quality and ultimately tree health. The goal of this meta-analysis was to assess the state of knowledge for organic materials in Arboriculture \& Urban Forestry, but future metaanalytical approaches should span entirety of scientific study.

\section{Acknowledgments}

The author gratefully acknowledges financial support from The Morton Arboretum Endowment and the Tree Research \& Education Fund, John Z. Duling grant (08-JD-05). I thank Doug Johnston and reviewers for thoughtful advice in preparing this manuscript.

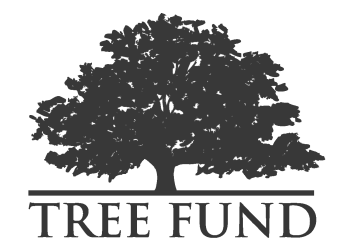

Tree Research \& Education Endowment Fund

\section{LITERATURE CITED}

Appleton, B.L., J.F. Derr, and B.B. Ross. 1990. The effect of various landscape weed control measures on soil moisture and temperature, and tree root growth. Journal of Arboriculture 16(10):264-268.

Arnold, M.A., G.V. McDonald, and D.L. Bryan. 2005. Planting depth and mulch thickness affect establishment of green ash (Fraxinus pennsylvanica) and bougainvillea goldenraintree (Koelreuteria bipinnata). Journal of Arboriculture 31(4):163-170.

Arthur, M.A., and Y. Wang. 1999. Soil nutrients and microbial biomass following weed-control treatments in a christmas tree plantation. Soil Science Society American Journal 63:629-637.

Bardgett. R. 2005. The Biology of Soil. Oxford University Press, New York. 242 pp.

Batjes, N.H., 1996. Total carbon and nitrogen in soils of the world. European Journal of Soil Science. 47:151-163.

Brady, N.C., and R.R. Weil. 2008. The Nature and Properties of Soils. 14th Edition. Pearson Prentice Hall, Upper Saddle River, NJ. 975 pp.

Burch, P.L., R.H. Wells, and W.N. Kline, III. 1996. Red maple and silver maple growth evaluated 10 years after application of pacloutrazol tree growth regulator. Journal of Arboriculture 22(2):61-66.

Chalker-Scott, L. 2007. Impact of mulches on landscape plants and the environment - a review. Journal of Environmental Horticulture 25(4):239-249.

Christiansen, E., R.H. Waring, and A.A. Berryman. 1987. Resistance of conifers to bark beetle attack: searching for general relationships. Forest Ecology and Management 22(1-2):89-106.

Close, R.E., P.V. Nguyen, and J.J. Kielbaso. 1996. Urban vs. natural sugar maple growth: I. stress symptoms and phenology in relation to site characteristics. Journal of Arboriculture 22(3):144-150.

Coleman, D.C., D.A. Crossley, Jr., and P.F. Hendrix. 2004. Fundamentals of Soil Ecology. 2nd Edition. Elsevier Academic Press. Burlingtion, MA. $375 \mathrm{pp}$.

Cooper H., and L.V. Hodges. 1994. The Handbook of Research Synthesis. Russell Sage Foundation, New York. 573 pp.
Craul, P.J. 1985. A description of urban soils and their desired characteristics. Journal of Arboriculture 11(11):330-339.

Craul, P.J. 1994. Soil compaction on heavily used sites. Journal of Arboriculture 20(2):69-74.

Craul, P.J. 1999. Urban Soils: Applications and Practices. John Wiley and Sons, Inc., New York. 366 pp.

Cregg, B.M. 1995. Plant moisture stress of green ash trees in contrasting urban sites. Journal of Arboriculture 21(6):271-276.

Curtis, P.S. 1996. A meta-analysis of leaf gas exchange and nitrogen in trees grown under elevated carbon dioxide. Plant, Cell, and Environment. 19:127-137.

Day, S.D., and J.R. Harris. 2007. Fertilization of red maple (Acer rubrum) and littleleaf linden (Tilia cordata) trees at recommended rates does not aid tree establishment. Arboriculture and Urban Forestry 33(2):113121.

Dixon, R.K., and P.S. Johnson. 1992. Synthesis of ectomycorrhizae on northern red oak seedlings in a Michigan nursery. Journal of Arboriculture 18(5):266-272.

Duchesne, L.C. and L.M. Clark. 1995. Wood chips as mulch for northern white cedar. Journal of Arboriculture 21(4):219-220.

Duryea, M.L., R.J. English, and L.A. Hermansen. 1999. A comparison of landscape mulches: chemical, allelopathic, and decomposition properties. Journal of Arboriculture 25(2):88-97.

Dyer, S.M., and D.L. Mader. 1986. Declined urban sugar maples: growth patterns, nutritional status and site factors. Journal of Arboriculture 12(1):6-13.

Evangelou, V.P. 1998. Environmental Soil and Water Chemistry: Principles and Applications. John Wiley and Sons, Inc., New York. 564 pp.

Ferrini, F., and M. Baietto. 2007. Effect of compost-amended backfill and paved surface on leaf parameters and physiology of Norway maple (Acer platanoides 1.). Arboriculture and Urban Forestry 33(6): 386-391.

Ferrini, F., A. Fini, P. Frangi, and G. Amoroso. 2008. Mulching of ornamental trees: effects on growth and physiology. Arboriculture and Urban Forestry. 34(3):157-162.

Ferrini, F., A. Giuntoli, F.P. Nicese, S. Pellegrini, and N. Vignozzi. 2005. Effect of fertilization and backfill amendments on soil characteristics, growth, and leaf gas exchange of english oak (Quercus robur 1.). Journal of Arboriculture 31(4):182-190.

Foshee, W.G., III, W.D. Goff, M.G. Patterson, K.M. Tilt, W.A. Dozier, Jr., L.S. Tucker, and J.S. Bannon. 1999. Organic mulches affect soil and leaf nutrient levels of young pecan trees. Journal of Arboriculture 25(2):81-84.

Fraedrich, S.W., and D.L. Ham. 1982. Wood chip mulching around maples: effect on tree growth and soil characteristics. Journal of Arboriculture 8(4):85-89.

Funk, R. 1983. An introduction to soils. Journal of Arboriculture 9(5):124-127.

Gilman, E.F. 2004. Effects of amendments, soil additives, and irrigation on tree survival and growth. Journal of Arboriculture 30(5):301-310.

Gilman, E.F., and J. Grabosky. 2004. Mulch and planting depth affect live oak (Quercus virginiana mill.) establishment. Journal of Arboriculture 30(5):311-317.

Glynn, C., D.A. Herms, M. Egawa, R. Hansen, and W.J. Mattson. 2003. Effects of nutrient availability on biomass allocation as well as constitutive and rapid induced herbivore resistance in poplar. Oikos 101(2):385-397.

Green, T.L., and G.W. Watson. 1989. Effects of turfgrass and mulch on the establishment and growth of bare-root sugar maples. Journal of Arboriculture 15(11):268-272. 
Greenly, K.M., and D.A. Rakow. 1995. The effect of wood mulch type and depth on weed and tree growth and certain soil parameters. Journal of Arboriculture 21(5):225-232.

Gurevitch, J., and L.V. Hedges. 1993. Meta-analysis: combining the results of independent experiments, pp 378-398. In Schneider, S.M. and J.S. Walsh (Eds.). Design and Analysis of Ecological Experiments. Chapmann and Hall, New York.

Hamilton, D.H., M.E.C. Grace, and S.D. Verkade. 1981. Critical effects of fertility on root and shoot growth of selected landscape plants. Journal of Arboriculture 7(11):281-290.

Hensley, D.L., R.E. McNeil, and R. Sundeim. 1988. Management influences on growth of transplanted Magnolia grandiflora. Journal of Arboriculture 14(8):204-207.

Herms, D.A. 2002. Effects of fertilization on insect resistance of woody ornamental plants: reassessing an entrenched paradigm. Environmental Entomology 31(6):923-933.

Herms, D.A., and W.J. Mattson. 1992. The dilemma of plants to grow or defend. Quarterly Review of Biology 67(3):283-355.

Himelick, E.B., and G.W. Watson, 1990. Reduction of oak chlorosis with wood chip mulch treatments. Journal of Arboriculture 16(10): 275-278.

Hoitink, H.A.J., A.F. Schmitthenner, and L.J. Herr. 1975. Composted bark for control of root rot in ornamentals. Journal of Arboriculture $1: 217-218$.

Hunter, J.E., and F.L. Schmidt. 2004. Methods of meta-analysis: correcting error and bias in research findings. SAGE Publications. $582 \mathrm{pp}$.

Iles, J.K., and M.S. Dosmann. 1999. Effect of organic and mineral mulches on soil properties and growth of fairview flame red maple trees. Journal of Arboriculture 25(3):163-167.

Jacobs, K.A. 2005. The potential of mulch to transmit three tree pathogens. Journal of Arboriculture 31(5):235-242.

Jarvinen, A. 1991. A meta-analytic study of the effects of female age on laying-date and clutch-size in the Great Tit Parus major and the Pied Flycatcher Ficedula hypoleuca. Ibis 133:62-67.

Jin, Z., B.Y. Chung, K. Iiyama, and S. Wantabee. 2002. Changes in chemical components of leaf litter of Ginkgo biloba during mulching. Journal of Arboriculture 28(4):171-177.

Kelsey, P.D., and R.G. Hootman. 1988. Soil resource evaluation for a group of sidewalk street tree planters. Journal of Arboriculture 16:113-117

Koski, R., and W.R. Jacobi. 2004. Tree pathogen survival in chipped wood mulch. Journal of Arboriculture 30(3):165-171.

Kozlowski, T.T. 1987. Soil moisture and absorption of water by tree roots. Journal of Arboriculture 13(2):39-46.

Lal, R., J.M. Kimble, and R. Follett. 1997. Soil Properties and Their Management for Carbon Sequestration. United States Department of Agriculture, Natural Resources Conservation Services, National Soil Survey Center. Lincoln, NE. 150 pp.

Lichter, J.M., and P.A. Lindsey. 1994. The use of surface treatments for the prevention of soil compaction during site construction. Journal of Arboriculture 20(4):205-209.

Lipsey, M.W. 1994. Identifying potentially interesting variables and analysis opportunities, pp. 111-123. In H. Cooper and L.V. Hedges (Eds.). The Handbook of Research Synthesis. Russell Sage Foundation, New York.

Litzow, M., and H. Pellet. 1983. Influence of mulch materials on growth of green ash. Journal of Arboriculture 9(1):77-11.

Lloyd, J.E., D.A. Herms, B.R. Stinner, and H.A.J. Hoitink. 2002. Com- paring composted yard trimmings and ground wood as mulches. Biocycle 43(9):52-62.

Lorio, P.L. 1986. Growth-differentiation balance: a basis for understanding sourthern pine-beetle tree interactions. Forest Ecology and Management 14(4):259-273.

Magdoff, F.R. 1996. Soil organic matter fractions and implications for interpreting organic matter tests, pp. 11-21. In F.R. Magdoff, M.A. Tabatabai, and E.A. Hanlon, Jr. (Eds.). Soil Organic Matter: Analysis and Interpretation. Soil Science Society of America Special Publication No. 56. Madison, WI.

Marx, D.H., M. Murphy, T. Parrish, S. Marx, D. Haigler, and D. Eckard. 1997. Root response of mature live oaks in coastal South Carolina to root zone inoculations with ectomycorrhizal fungal inoculants. Journal of Arboriculture 23(6):257-263.

Matson, P.A., and R.H. Waring. 1984. Effects of nutrient and light limitation on mountain hemlock: susceptibility to laminated root-rot. Ecology 65(5):1517-1524.

Maynard, A.A. 1998. Utilization of MSW compost in nursery stock production. Compost Science and Utilization 6:38-44.

McPherson, E.G. 1998. Atmospheric carbon dioxide reduction by Sacremento's urban forest. Journal of Arboriculture 24(4):215-223.

Melillo, J.M., J.D. Aber, and J.F. Muratore. 1982. Nitrogen and lignin control of hardwood leaf litter decomposition dynamics. Ecology 63(3):621-626

Myers, M.K., and H.C. Harrison. 1988. Evaluation of container plantings in an urban environment. Journal of Arboriculture 14(12):293-297.

Montague, T., C. McKenney, M. Maurer, and B. Winn. 2007. Influence of irrigation volume and mulch on establishment of select shrub species. Arboriculture and Urban Forestry 33(3):202-209.

Northup, R.R., Z. Yu, R.A. Dahlgren, and K.A. Vogt. 1995. Polyphenol control of nitrogen release from pine litter. Nature 377(6546):227-229.

Nowak, D.J., J.C. Stevens, S.M. Sisinni, and C.J. Luley. 2002. Effects of urban tree management on atmospheric carbon dioxide. Journal of Arboriculture 28(3):113-122.

Paul, E.A. 2007. Soil Microbiology, Ecology, and Biochemistry. 3rd Edition. Academic Press, Burlington, MA. 532 pp.

Peck, T.R. 1981. What to expect from soil tests. Journal of Arboriculture 7(1):11-12.

Pellet, H. 1971. Effect of soil amendments on growth of landscape plants. American Nurseryman 134(12):103-106.

Perry, E. and G.W. Hickman. 1998. Correlating foliar nitrogen levels with growth in two landscape tree species. Journal of Arboriculture 24(3):149-153.

Pickering, J.S. and A. Shepard. 2000. Evaluation of organic landscape mulches: composition and nutrient release characteristics. Arboricultural Journal 23:175-187.

Poulin, R. 1994. Meta-analysis of parasite-induces behavioural changes. Animal Behaviour 48:137-146.

Rechcigl, J.E. 1995. Soil Amendments and Environmental Quality. CRC Press. Boca Ratton, FL. 504 pp.

Rivenshield, A., and N.L. Bassuk. 2007. Using organic amendments to decrease bulk density and increase macroporosity in compacted soils. Arboriculture \& Urban Forestry 33(2):140-146.

Roberts, B.R. 2006. Compost-containing substrates and their effect on posttransplant growth of containerized tree seedlings. Arboriculture \& Urban Forestry 32(6):289-296

Rühlmann, J., M. Körschens, and J. Graefe. 2006. A new approach to calculate the particle density of soils considering properties of the soil organic matter and the mineral matrix. Geoderma 130(3-4):272-283. 
Scharenbroch, B.C., and J.E. Lloyd. 2004. A literature review of nitrogen availability indices for use in urban landscapes. Journal of Arboriculture 30(4):214-230.

Scharenbroch, B.C., and J.E. Lloyd. 2006. Particulate organic matter and soil nitrogen availability in urban landscapes. Arboriculture \& Urban Forestry 32(4):180-191.

Schulte, J.R., and C.E. Whitcomb. 1975. Effects of soil amendments and fertilizer levels on the establishment of silver maple. Journal of Arboriculture 1:192-195.

Sikora, L.J., C.A. Cambardella, V. Yakovchenko, and J. Doran. 1996. Assessing soil quality by testing organic matter, pp. 41-50. In F.R. Magdoff, M.A. Tabatabai, and E.A. Hanlon, Jr. (Eds.). Soil Organic Matter: Analysis and Interpretation. Soil Science Society of America Special Publication No. 56. Madison, WI.

Singer, C.K., and C.A. Martin. 2008. Effect of landscape mulches on desert landscape microclimates. Arboriculture \& Urban Forestry 34(4):230-237.

Smalley, T.J., and C.B. Wood. 1995. Effect of backfill amendment on growth of red maple. Journal of Arboriculture 21(5):247-250.

Smiley, E.T., D.H. Marx, and B.R. Fraedrich. 1997. Ectomycorrhizal fungus inoculations of established residential trees. Journal of Arboriculture 23(3):113-115.

Smith, A.M., and D.A. Rakow. 1992. Strategies for reducing water input in woody landscape plantings. Journal of Arboriculture 18(4):165-170.

Smith, E.M. 1979. Weed control in the landscape. Journal of Arboriculture 5(3):51-58.

Soloman, S., D. Qin, M. Manning. 2007. Climate Change 2007: The Physical Science Basis. Working Group I Contribution to the 4th Assessment, Report of the Intergovernmental Panel on Climate Change. $142 \mathrm{pp}$.

Steward, L.G., T.D. Syndor, and B. Bishop. 2003. The ease of ignition of 13 landscape mulches. Journal of Arboriculture 29(6):317-321.

Stinson, J.H., G.H. Brinen, D.B. McConnell, R.J. Black. 1990. Evaluation of landscape mulches. Proceedings from Florida State Horticulture Society 103:372-377.

Stratton, M.L., A.V. Barker, and J.E. Rechcigl. 1995. Compost, pp. 249310. In J.E. Rechcigl (Ed.). Soil Amendments and Environmental Quality. CRC Press. Boca Ratton, FL.

Struve, D.K. 2002. A review of shade tree nitrogen fertilization research in the United States. Journal of Arboriculture 28(6):252-263.

Swisher, B.E. 1976. Alternative uses of wood chips. Journal of Arboriculture 2:13-16.

Sylvia, D.M., J.J. Fuhrman, P.G. Hartel, and D.A. Zuberer. 1999. Principles and Applications of Soil Microbiology. Prentice Hall, Upper Saddle River, NJ. 550 pp.

Szwedo, J., and M. Maszczyk. 2000. Effects of straw-mulching of tree rows on some soil characteristics, mineral nutrient uptake and cropping of sour cherry trees. Journal of Fruit and Ornamental Plant Research 8:147-153.
Tabatabai, M.A. 1996. Soil organic matter testing: an overview, pp. 1-9. In Magdoff, F.R., M.A. Tabatabai, and E.A. Hanlon, Jr. (Eds.). Soil Organic Matter: Analysis and Interpretation. Soil Science Society of America Special Publication No. 56. Madison, WI.

Tilander, Y., and M. Bonzi. 1997. Water and nutrient conservation through the use of agroforestry mulches, and sorghum yield response. Plant and Soil 197:219-232.

van de Werken, H. 1981. Fertilization and other factors enhancing the growth rate of young shade trees. Journal of Arboriculture 7(2):33-37.

Wager, J.A., and P.A. Barker. 1993. Effectiveness of three barrier materials for stopping regenerating roots of established trees. Journal of Arboriculture 19(6):332-338.

Walker, D.K. 1977. Turning liabilities into assets: organic mulching. Journal of Arboriculture 3(10):197-200.

Watson, G. 1991. Attaining root:crown balance in landscape trees. Journal of Arboriculture 17(8):211-216.

Watson, G.W. 1988. Organic mulch and grass competition influence tree root development. Journal of Arboriculture 14(8):200-203.

Watson, G.W. 2002. Soil replacement: long-term results. Journal of Arboriculture 28(5):229-230.

Watson, G.W., and G. Kupkowski. 1991. Effects of a deep layer of mulch on the soil environment and tree root growth. Journal of Arboriculture 17(9):242-245.

Watson, G.W., G. Kupkowski, and K.G. von der Heide-Spravka. 1992. The effect of backfill soil texture and planting hole shape on root regeneration of transplanted green ash. Journal of Arboriculture 18(3):130-135.

Watson, G.W., P. Kelsey, and K. Woodtli. 1996. Replacing soil in the root zone of mature trees for better growth. Journal of Arboriculture 22(4):167-173.

Wells, C., K. Townsend, J. Caldwell, D. Ham, E.T. Smiley, and M. Sherwood. 2006. Effects of planting depth on landscape tree survival and girdling root formation. Arboriculture \& Urban Forestry 32(6): 305-311.

Whitcomb, C.E. 1979. Factors affecting the establishment of urban trees. Journal of Arboriculture 5(10):217-219.

Whitcomb, C.E. 1980. Effects of black plastic and mulches on growth and survival of landscape plants. Journal of Arboriculture 6(1):10-12.

Whitcomb, C.E. 1981. Response of woody landscape plants to bermudagrass competition and fertility. Journal of Arboriculture 7(7):191-194.

Zajicek, J.M. 1993. Design and testing of urban landscapes for water conservation. Journal of Arboriculture 19(1):1-6.

Bryant C. Scharenbroch

The Morton Arboretum

4100 Illinois Route 53

Lisle, IL 60532 4293, U.S. 
Zusammenfassung. Organisches Material wird gewöhnlich im Landschaftsbau zur Verbesserung von Boden, Bäumen und Umwelt eingesetzt. Eine Literaturübersicht zeigt, dass die Einflüsse von organischem Material positiv sind, aber dass diese Einflüsse noch durch meta-analytische Ansätze bewertet werden müssen. Diese Studie präsentiert eine Literatursammlung von 176 in der AUF veröffentlichten Artikeln und bewertet 33 davon mit Hilfe einer Meta-Analyse. Die themenrelevante Forschung wurde nicht nur in der AUF publiziert, aber die Meta-Analyse ist begrenzt auf die AUF in einem Versuch, einen Fokus auf die Information von AUF-Lesern zu richten. Diese Meta-Analyse liefert den Nachweis für höchst positive Einflüsse von organischem Material auf das Trieb- und Wurzelwachstum, Baumphysiologie und Bodenphysik. Es identifiziert auch Lücken in der AUF-Literatur bezüglich der Einflüsse organischen Materials auf Bodenchemie, -biologie und Umweltbedingungen. Darüberhinaus zeigt es, dass der Typ des organischen Materials und seine Aufbereitung unterschiedlicheWirkungen in Boden, Bäumen und Umwelt verursachen.
Resumen. Los materiales orgánicos son comúnmente usados en paisajes urbanos para mejorar el suelo, los árboles y la salud ambiental. Las revisiones de literatura sugieren que los efectos de los materiales orgánicos son benéficos, pero estos impactos deben ser evaluados usando aproximaciones meta-analíticas. Este trabajo presenta un resumen de literatura de 176 artículos publicados en Arboriculture \& Urban Forestry $(A U F)$ y evalúa 33 de estos reportes usan meta-análisis. La investigación relevante a este tópico no está publicada solamente en $A U F$, pero el meta-análisis está limitado a $A U F$ en un intento de especificar la información provista a los lectores de $A U F$. Este meta-análisis provee evidencia de los impactos mayormente positivos que los materiales orgánicos tiene en el crecimiento de los brotes, crecimiento de raíces, fisiología del árbol y propiedades físicas del suelo. También se identifican espacios en la literatura de $A U F$ para ver los efectos que los materiales orgánicos tienen en la química del suelo, biología del suelo, propiedades ambientales (clima, competencia, etc.). Además, este metaanálisis sugiere el tipo de material orgánico y el modo en que la aplicación tiene efectos diferentes en el árboles, suelo y propiedades ambientales. 